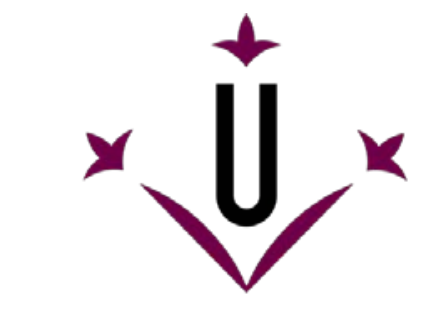

Universitat de Lleida

Document downloaded from:

http://hdl.handle.net/10459.1/66139

The final publication is available at:

https://doi.org/10.1080/09668136.2017.1401592

Copyright

(c) Taylor \& Francis, 2017 


\title{
Railway Development and the Economic and Political Integration of the Balkans, c. 1850-2000
}

\author{
KALOYAN STANEV, EDUARD JOSEP ALVAREZ-PALAU \&
} JORDI MARTÍ-HENNEBERG

Abstract

This article uses the evolution of the railways to examine the relationship between the level of economic integration and external political influences in the Balkans over a period of 150 years. The analysis focuses on two key themes: the long-term spatial evolution of the railway network and external influences on this infrastructure. To undertake this territorial analysis, we first established a Historical Geographical Information System (HGIS) that allowed us to interpret data on the evolution of the railway network and then related this to other data on themes such as changing international borders and the nationality of investment.

THIS ARTICLE FOCUSES ON THE EVOLUTION OF RAILWAYS IN THE BALKANS and, more particularly, on the relationship between railway construction and political transformation in a region that has become synonymous with instability and political fragmentation. The research covers the period between the construction of the firstrailway lines, in around 1850, and the end of the twentieth century. Throughout the world, railways were a key innovation during the Industrial Revolution and fostered the integration of national and international markets (Rostov 1953; Keller \& Shiue 2008; Donaldson \& Hornbeck 2013). In general, more railways and larger rail networks tended to point to greater economic growth as a result of increased trade and a greater degree of economic integration (O’Brien 1983; Caruana-Galizia \& Martí-Henneberg 2013). Although one of the major challenges yet to be resolved from the academic point of view concerns the nature of the causality between the development of railway networks and economic growth, there is a general consensus that the two processes were closely related.

We would like to acknowledge the help that we received from the referees and Dr Toader Popescu and to thank them for their comments on this article. The research leading to these results was provided by the Ministerio de Economia y Competitividad (CSO2015-65733-P); the EU (Jean Monnet 586912-EPP1-2017-1-ES-EPPJMO); and ICREA, Generalitat de Catalunya. This work was carried out while Jordi Martí-Henneberg was a visiting scholar at the Department of Geography, University of Cambridge.

This work was supported by the European Union (EU; Jean Monnet) [grant number 586912-EPP-1-2017-1ES-EPPJMO]; the ICREA, Generalitat de Catalunya [grant number 2013-2017]; the Ministerio de Economia y Competitividad [grant number CSO2015-65733-P]. 
The construction of railways during the late nineteenth and early twentieth centuries was one of the key factors that shaped political and economic development in the Balkans during this period. Most of the previous works on this subject focused on the political and financial aspects of the expansion of the Balkan railway network. Among others, Hertner (2006) studied the financing of the Balkan railways; Lampe and Marvin (1982) and Palairet (1997) presented a detailed study of political struggles in the Balkans and their economic consequences for railways; Nikova (2007) focused on the lack of cooperation between the Balkan states regarding the development of the region's infrastructure; Pamuk (1987) and Bilmez (2008) provided an insight into the impact of foreign investment on the railways of the Ottoman Empire; and Popescu (2014) and Turnock (1979, 1986, 1989, 2001, 2006) explored social and economic issues related to the construction of railways in Romania and the Balkans. The impact of the region's unstable borders on the development of its railway network has so far received little attention in the literature, with only a few notable exceptions (Wolfe 1963; Turnock 1979; Howkins 1999; Stanev 2013). The lack of territorial stability and the shortage of reliable and internationally comparable information have also greatly limited the possibility of conducting long-term historical studies covering the whole Balkan region. As a result, national case studies predominate in the literature on this subject. By employing a Historical Geographical Information System (hereinafter HGIS) and both by using new data and by applying existing data in innovative ways, we have been able to analyse the evolution of the Balkan railway networks at the national and transnational levels and thereby complement the existing literature.

One of the main determinants of the impact of railway construction is the location of the routes created. However, decisions and reasons concerning where to build railways are not always determined purely by demand, as confirmed by numerous cases studies. For example, Duranton and Turner (2012) demonstrate that railways in the US were built where land and labour were cheap, not where they were necessarily needed. Similarly, Mojica and MartíHenneberg (2011) have found evidence that the construction of railways in Spain was rarely driven by demand but more by a perceived need to connect political and administrative capitals.

30 Similarly, in the Balkans, the construction of railways has been subjected to strong external influences. Our hypothesis is that the routes and the subsequent level of integration of the Balkan railway networks have been greatly influenced by the level of economic and political autonomy of the different states in the region. First, the Austro-Hungarian and Ottoman empires dominated the region until the Balkan Wars (1912-1913) and World War I; then, during the Cold War, the Soviet Union had significant influence over several states in the region. The degree of railway integration improved during these periods of strong external influence and tended to stagnate when the countries in this region enjoyed greater independence and were able to plan their railway networks with greater autonomy.

Since the development of railways tends to be closely related to economic integration, which was particularly true during the nineteenth and twentieth centuries, we can go a step further and argue that the economic integration of the Balkans improved most during periods of strong external influence but stagnated, or even declined, during periods when the Balkan states enjoyed more autonomy. In order to test this hypothesis, we evaluated the economic influences in the Balkan states by examining the nationality of the promoters of their railways. 
the goals of those who financed these railways were during each period of its construction. We subsequently focused our attention on the spatial evolution of the different railway networks and on establishing criteria with which to measure their level of integration. Using information within a HGIS format, we calculated a set of indicators: spatial extension and total length of the railway network, index of railway coverage, network density, line hierarchy, border permeability, and route factor. These indicators allowed us to make comparisons over time and between different territories. They also allowed us to analyse relationships between the political and economic influences prevalent during different historical periods and the evolution of the different railway networks.

\section{Data and methodology}

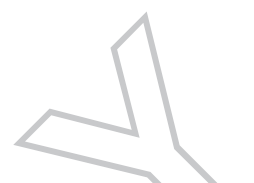

The study examined the area occupied by 12 modern-day states: Albania, Bosnia \& Hercegovina, Bulgaria, Croatia, Greece, Macedonia, Montenegro, Romania, Serbia, Slovenia, Kosovo (which has partial international recognition) and the European part of Turkey. The region that we will refer to as 'the Balkans' in the current article covers more than $750,000 \mathrm{~km}^{2}$ (Todorova 1997). ${ }^{1}$ Our analysis covers a period (1850-2000) that saw numerous modifications to the political map of the region, with states emerging and disappearing and their borders constantly changing (Jelavich \& Jelavich 1977). The most far-reaching border changes occurred in 1878, between 1912 and 1919, and in the 1990s (see the map series in Figure 1). The changes in the first two periods were the result of the disintegration of the multi-ethnic Austro-Hungarian and Ottoman empires and the emergence of a number of new independent nation states towards the end of the nineteenth century and in the early twentieth century; the latter were the result of the dissolution of the multi-ethnic state of Yugoslavia. The long-term approach adopted in the current work required the use of historical data relating to states that no longer exist but which played important roles in the past: the former Austro-Hungarian Empire, the Ottoman Empire, and Yugoslayia.

Our analysis was based on three key elements: railway lines, investments, and national borders. The HGIS dataset that we obtained integrated two of these variables (national borders and railway lines) at two separate geographical layers. We then used the results to track the evolution of border changes and the railway lines in service at ten-year intervals. The sources used for the HGIS were the Digital Chart of the World, the website of The History of European Railways, the website of 'Railways through Europe', and local databases for each of the countries cited in Morillas-Torné (2012) and in Martí-Henneberg (2013). ${ }^{2}$ The data on territorial change were obtained from Kraus et al. (2018) and from Stanev (2011).

${ }^{1}$ The definition of exactly which states belong to 'the Balkans' depends on the criteria that are applied. The Balkan Peninsula is the geographic region defined by the Adriatic Sea to the west, the Mediterranean Sea to the south, the Black Sea to the east and the Danube, Sava, and Kupa rivers to the north. In contrast, the terms 'the Balkans' and Southeast Europe refer to a geopolitical and cultural region of Europe. As in the current study, this not only refers to the countries that are located within the geographical borders of the Balkan Peninsula, but also to some countries that have been historically and culturally related to this region.

${ }^{2}$ The Digital Chart of the World (DCW) is a comprehensive geographical information system (GIS) global database that is freely available, although it has not been updated since 1992; The History of European Railways (Histoire chronologique des chemins de fer européens) is available at: http://www.train.eryx.net/html_trains/index_nouveau.htm, accessed 1 November 2017; Railways through Europe is available at: http://www.bueker.net/trainspotting/, accessed 1 November 2017. 


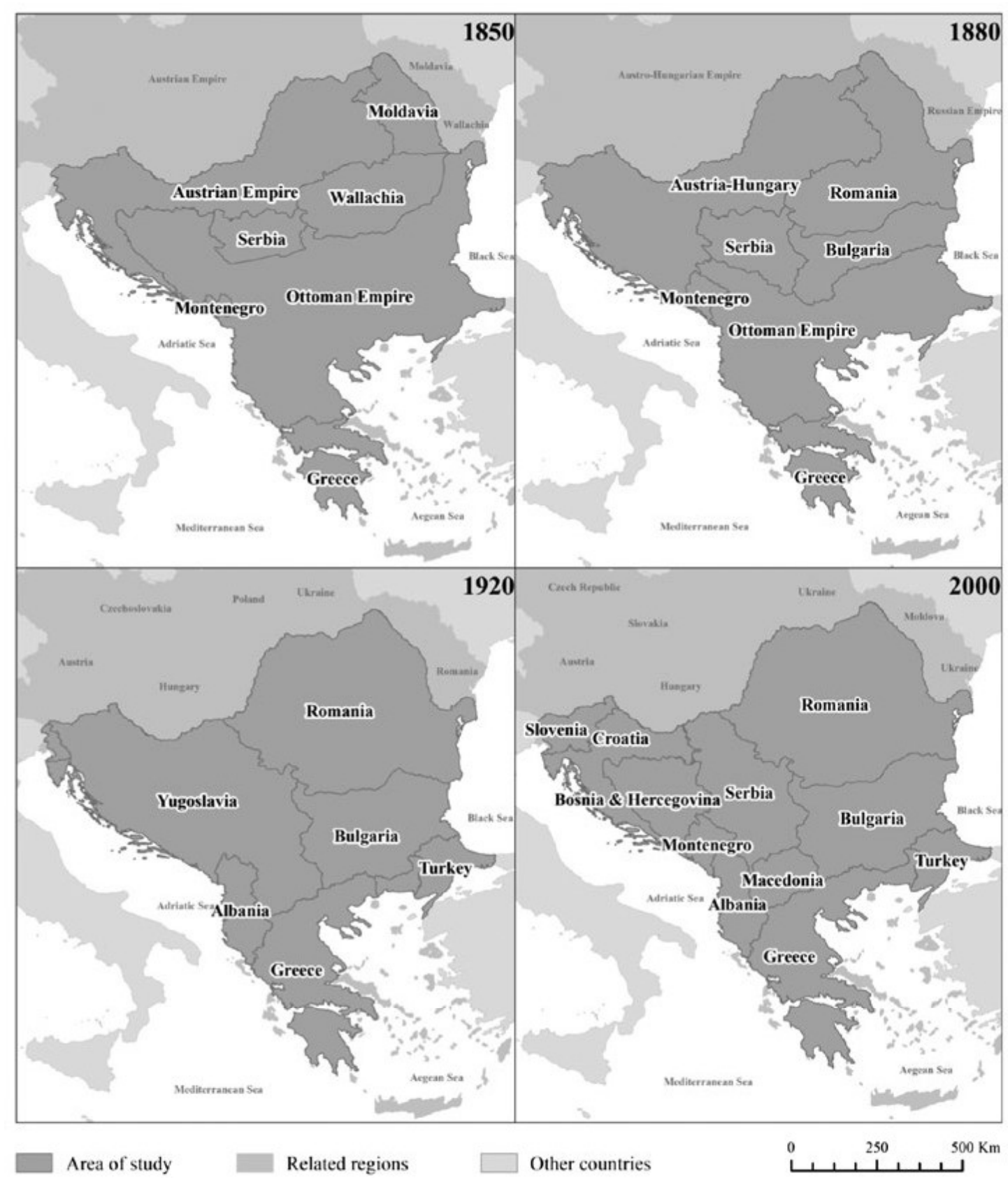

Figure1. Evolution of Political Borders in the Area of Study.

Source: Kraus et al. (2018).

The third variable, which referred to the nationality of the promoter of each railway line, was incorporated into the GIS database as an attribute of the different railway lines. Identifying the promoter was a challenging task as there were a number of different funding mechanisms. The first strategy involved private planning and investment; this tended to be foreign in origin and a response to the lack of locally available capital. The second was the construction of lines planned by national governments but financed by private investors. The third, and most prevalent, strategy — which was most evident during the later stages of network development-was the construction of lines by governments themselves. In this last case, 
projects were funded either from the country's own resources or with loans obtained from foreign banks. For the purposes of our study, the nationality of the original constructor of each railway line is the most interesting factor. Thus, lines constructed by governments using their own resources or foreign loans were considered 'national', while those constructed privately, including via concessions, were attributed to the nationality of the company or organisation that built them. This information was obtained from secondary sources: Lampe and Marvin (1982) and Palairet (1997) for railway lines in Romania, Greece, Austria-Hungary, and Serbia; Bilmez (2008) for lines in the Ottoman Empire; and Ivanov et al. (2009) for lines in Bulgaria.

We identified three key periods in the development of the region's railway networks, each of which presented us with particular challenges. In order to test our hypothesis, we used spatial indices for each period and graph theory tools (Hagget 1977; Kansky \& Danscoine 1989; Dupuy 1991) to correlate the three previously mentioned variables. The first indicator considered was the territorial coverage of the railway system. To calculate this, we first delimited a $10 \mathrm{~km}$ buffer zone around the different railway lines (corresponding to a twohour journey on foot) and then merged data for neighbouring lines. In the existing literature, coverage has tended to be calculated (Gastner \& Newman 2006; Alvarez et al. 2013) using railway stations as reference access nodes between the rail transport network and the local territory. However, we did not have reliable data for the whole territory concerning when railway stations opened and closed. We therefore opted to consider territories located near railway lines as connected to the rail network and those that were distant from it as unconnected (Franch et al. 2013). Another indicator was used to distinguish between those lines that crossed international borders and the many others that did not. Based on this variable, it was possible to introduce another complementary indicator: border permeability, which took into account the number of railway lines that crossed international borders.

For the purposes of our study, it was necessary to determine whether the lines constructed with foreign capital and those built by the states in the region, using national funding, followed the same or different logics. To answer this question, we ranked the different lines according to their relative importance, using a three-level classification: international, primary, and secondary. We classified lines that connected major cities in different countries or major cities to leading ports as 'international', as they permitted the transnational movement of goods and passengers. The other lines were considered 'domestic' and divided into two groups. Lines that connected national capitals to other important cities, but did not provide international connections, were classified as 'primary'. On the other hand, branch lines of only local importance were classified as 'secondary' (see Figure 2).

Another important variable was the route factor (Blunden 1971; Bouwman \& Moll 2002; Gastner \& Newman 2006), which was used to compare the relationship between the real distance between two nodes when travelling by rail and the straight-line distance between the same two points. In this way, it was possible to obtain a coefficient that gave an indication of the directness of the relationship between key points in the network, such as capitals.

In this project, we have only considered standard-gauge railways. The main reason for this was the lack of complete geographical information on the historical evolution of narrow-gauge lines and the fact that narrow-gauge lines have tended to play only a regional role. Even so, we were able to aggregate data on the total length of this type of railway and to assess the relative importance of narrow-gauge lines in each of the countries studied (see Figure 3). 


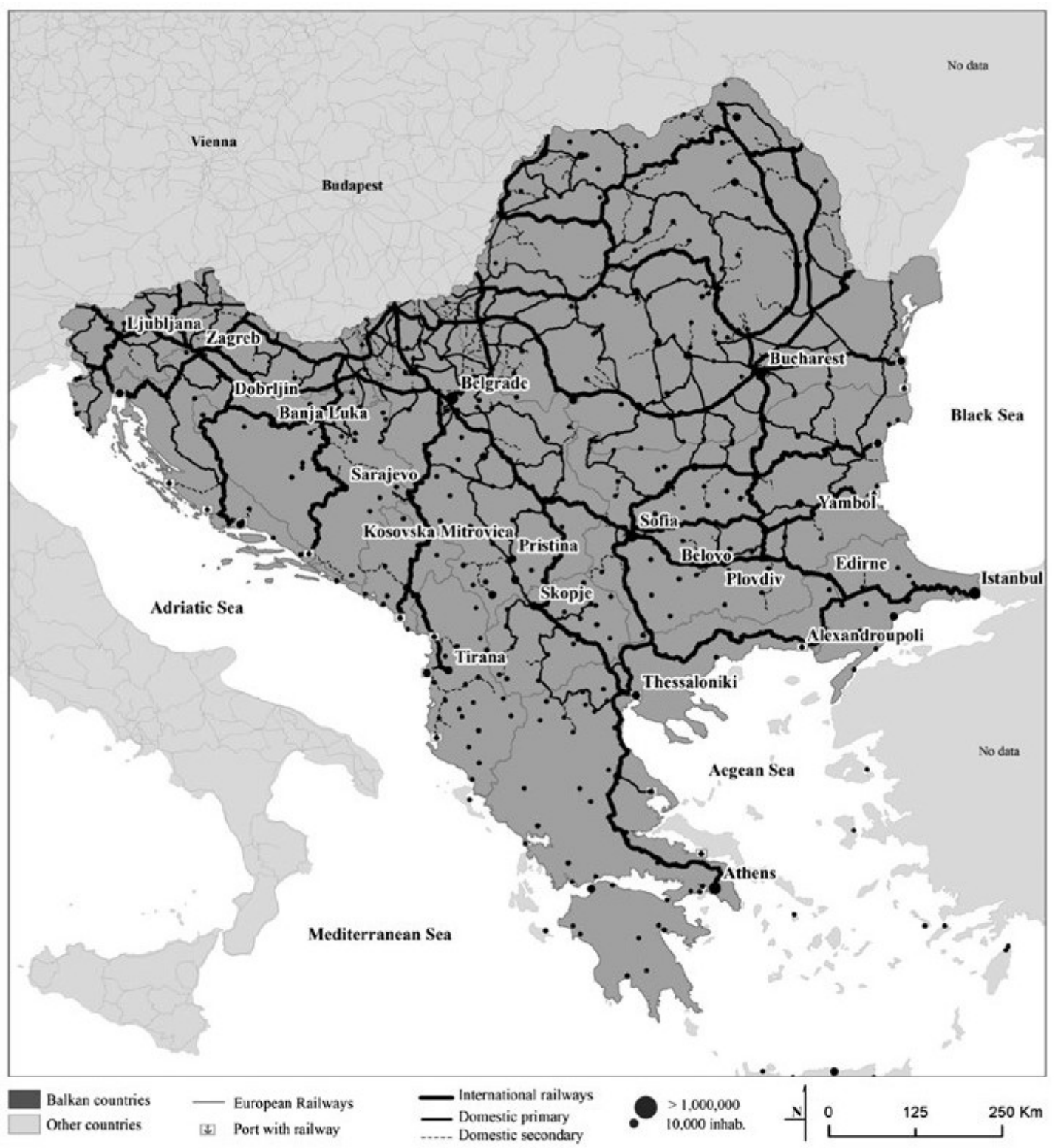

FIGURE 2. RAILWAY LinES IN THE REgION ACCORDING TO THEIR HIERARCHY. Sources: Own estimations based on HGISE (2015) and Stanev (2013).

In Bulgaria, the first narrow-gauge lines were constructed in 1910, and by 1940 the total length of this track had reached approximately $500 \mathrm{~km}$. However, the use of narrow-gauge track in Bulgaria subsequently declined, and today there is only $124 \mathrm{~km}$ of this type of track. The case of Romania was similar: by 1930, there was already approximately $350 \mathrm{~km}$ of narrow-gauge track in service. This remained the case until the $1970 \mathrm{~s}$, when more than $100 \mathrm{~km}$ of track was closed, while by 2000, all the country's narrow-gauge lines had been closed.

In these and other Balkan states, narrow-gauge lines played only a complementary role. However, they seem to have played a more important role in the development of the railway networks of Greece and Bosnia \& Hercegovina (see Figure 3), where narrow gauge lines constituted the main type of railway infrastructure. These two states had very limited standardgauge rail coverage, but almost 1,500 km of narrow-gauge track. The Greek narrow-gauge 

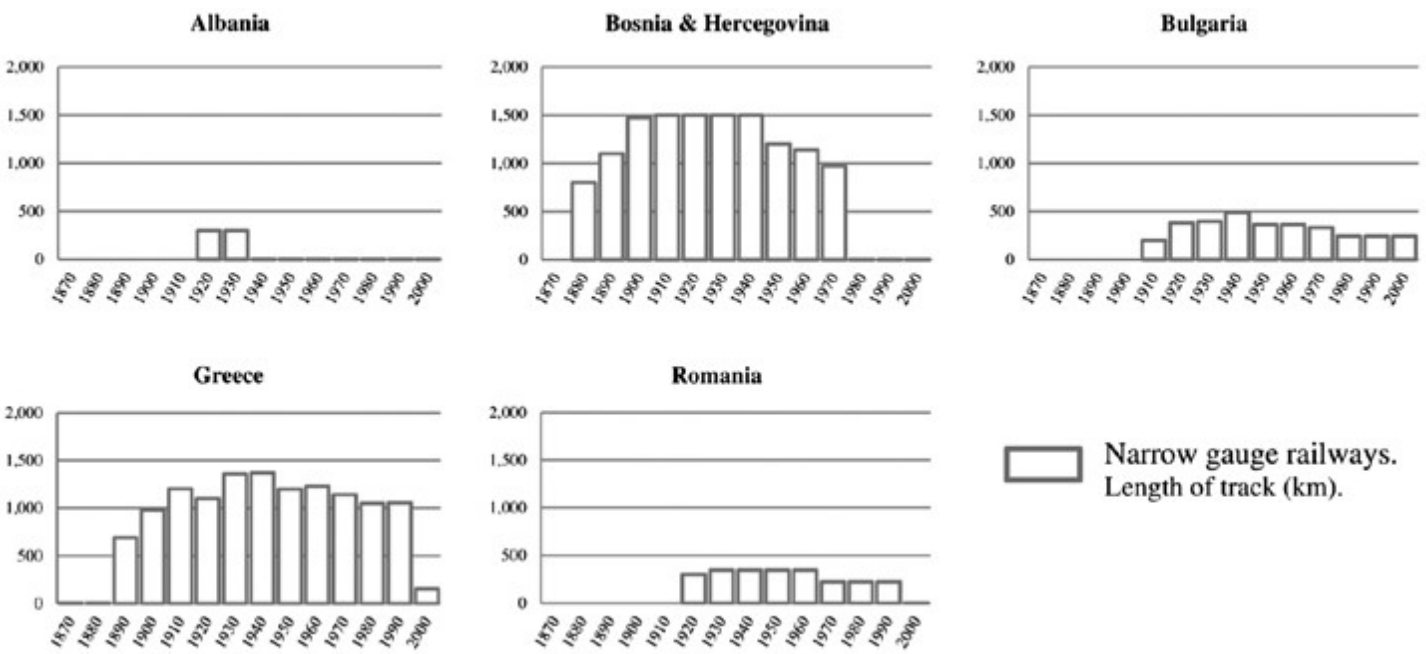

$\square$ Narrow gauge railways. Length of track $(\mathrm{km})$.

FIGURE 3. EVOLUTION OF THE LENGTH OF NARROW-GAUGE TRACK BY COUNTRY (USING CURRENT BOUNDARIES).

Sources: Chester (2006) for Bosnia \& Herzegovina; Organ (2008) for Romania; Deyanov (2005) for Bulgaria; Zartaloudis et al. (1997) for Greece.

network reached its maximum extension in the 1940s, before going into decline. In Bosnia, the situation was similar, with peak network extension reached in the 1910s and maintained until the 1950s, before its subsequent decline. We should also underline the fact that the gauges used in these two states were different. Greece mainly had a one-metre gauge railway, while in Bosnia \& Hercegovina the gauge used was $760 \mathrm{~mm}$, which came to be known as 'Bosnian gauge'.

The Greek railway network remained effectively isolated, while the Bulgarian and Romanian networks played only a complementary role. As a result, considering the narrowgauge lines in these countries would not have affected the main conclusions drawn from this study with regard to the integration of the overall railway network. The case of Bosnia \& Hercegovina presented us with a more complex dilemma: if we had included data on the Bosnian narrow-gauge lines in our calculations, this would have had a significant impact on the overall connectivity of the railway network. However, the inclusion of data on narrowgauge tracks in Bosnia would almost certainly have strengthened our conclusions regarding the fragmentation of the railway network because it was not technically possible to connect the Bosnian narrow-gauge network to the standard network used in the other Balkan countries.

\section{The evolution of the Balkan railway network}

In the nineteenth century, the main exports from the Balkans were based on raw materials that were moved either by water-rivers, canals (in the Hapsburg Empire), and sea—or land,

20 predominantly using traditional horse-and-cart transport or, in some cases, camels (Lampe \& Marvin 1982). The mountainous terrain, poor roads, and lack of security made land transport expensive and unreliable, so long-distance trade tended to be predominantly conducted via river and sea ports (Kostov 1995). High transport costs hampered economic growth and railways soon became seen as vital for achieving modernisation. Even so, in a context of low industrial development and a lack of local capital (Lampe 1975), the Balkan railway network developed several decades later than those in the core areas of Western and Central 
Europe. The first railway lines were opened in the 1840 s, in territories controlled by what was then the Austrian Empire. This rail network then expanded over the next three decades, but only as far as the borders of the empire. Meanwhile, the rest of the Balkans-most of which was ruled by the Ottoman Empire-remained largely unaffected by the transport revolution. This situation changed during the late 1860s, when rail construction began in Romania and the Ottoman Empire (Turnock 2001; Ehrlich 1985). The greatest intensity of construction occurred between 1870 and 1900 , with some $4,000 \mathrm{~km}$ of new track coming into service in each decade. Construction peaked in the $1890 \mathrm{~s}$, when more than $4,500 \mathrm{~km}$ of new track was built. By the beginning of the twentieth century, the Balkans network already included some $15,000 \mathrm{~km}$ of standard-gauge and $2,400 \mathrm{~km}$ of narrow-gauge track. Thereafter, railway construction continued at a slower pace, with no more than $2,000 \mathrm{~km}$ of new track constructed in any decade until the 1970s (Stanev 2013).

We have divided the evolution of the railway system in the region into three different periods. The first period began with the opening of the first railway lines and ended with the Balkan Wars (1912-1913) and World War I. These transformed the political and economic realities of the Balkans to such an extent that we considered the time after these wars to constitute a new period of railway construction. This was further confirmed by both the type and ownership of the new lines constructed. The second period continued until the 1960s, as the data collected clearly identify the 1960s as the inflection point that brought the expansion of the Balkan rail network to an end. As a result, we considered the subsequent years as constituting a new period characterised by the stagnation of railway construction until the end of the Cold War, followed by a minor, but clearly visible, decline throughout the 1990s.

\section{The Balkan railways before World War I}

The development of the region's railway networks before World War I was marked by the interaction of two, often contrasting, strategies. The first was the construction of the main tracks, which was largely funded by foreign investors. Throughout the nineteenth century, the combination of a lack of local capital, low population densities, and economic backwardness meant that the local economies of the Balkan states were unable to finance capital-intensive railway projects. As a result, the Balkan railway lines were initially built with capital from

30 France, Britain, and Germany (Hertner 2006). The European powers mainly financed these railway lines in order to connect Europe to the Middle East (Berend \& Ranki 1969; Ehrlich 1986; Pamuk 1987; McMeekin 2010). The second strategy was to promote national rail AQ5 networks for the new nation states that had emerged in the Balkans. In this political context, the networks were mainly shaped around: the old imperial capitals (Vienna, Budapest, and Istanbul); the capitals of the newly independent Balkans states (Bucharest, Athens, Sofia, and Belgrade); and ports on the River Danube and the Adriatic, Mediterranean, Aegean, and Black seas.

The two main powers in the Balkans-the Ottoman and Austro-Hungarian empiresfollowed their own strategies, building railway networks within their respective territories. During the initial wave of railway construction, in the 1840s and 1850s, the Austro-Hungarian state mainly funded these operations itself. After 1854, railway construction largely continued through private concessions. However, in 1873, several Austrian railway companies went bankrupt and, as a result, the state had to once more take the initiative in developing the national railway network (Ehrlich 1985; Purcar 2010). In order to understand the configuration 


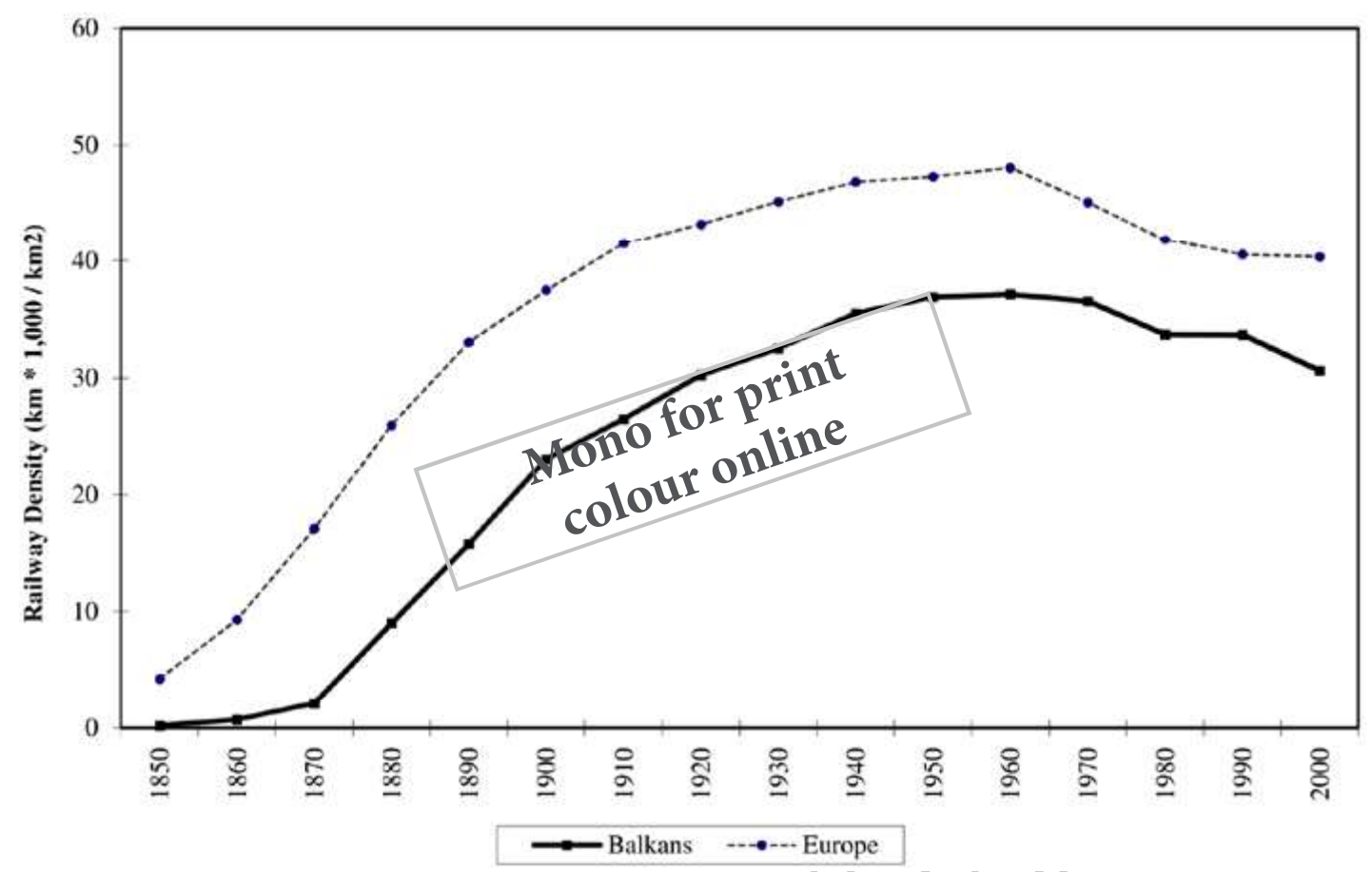

FIGURE 4. COMPARATIVE StUdy OF THE Densities OF THE RAIlWAY NeTwORKS IN THE BALKANS AND EUROPE: 1850-2000.

Sources: HGISE (2015) for Europe; Stanev (2013) for the Balkans.

of the railway network in the Western Balkans, it is necessary to consider the ongoing struggle for dominance between the Austrian and Hungarian authorities. This had a major influence on the spatial development of the empire's railway network, which was structured around two major hubs - Vienna and Budapest — with the main routes running roughly north-south and connecting industrial centres, such as Silesia, to Vienna and the Adriatic coast (Turnock 2006).

In the second half of the nineteenth century, the other power in the Balkan regionthe declining Ottoman Empire-also sought to introduce this technological advance into its territories. It was thought that railways would increase fiscal revenues, facilitate the deployment of troops, and open up new opportunities for trade with Western Europe. However, the Ottomans had to apply a different strategy: due to a lack of domestic capital and technical expertise, their lines were built and operated by foreign investors under state concessions. In the European part of the Ottoman Empire, growing German economic interests in the Balkans and the Middle East eventually served as the driving force behind the development of the railway network (Pamuk 1987; McMeekin 2010).

The most important railway builder involved in the European part of the Ottoman Empire was Chemins de fer Orientaux (CO), a company founded by a German entrepreneur of Jewish origin, Baron Moritz von Hirsch. By 1874, CO had completed over 1,300 km of railway track, including the three main railway lines running through the European territories of the Ottoman Empire (Pamuk 1987). The longest and most important of these lines was that running from İstanbul to Belovo (Bulgaria) via Edirne and Plovdiv, which included branch lines to Alexandropoulos and Yambol (see Figure 2). The other two ran from Thessaloniki to Mitroviça and from Dobrljin to Banja Luka (see Figure 5). The construction of these major routes was not affected by the limitations imposed by national borders as these did not appear until after 1878 . 


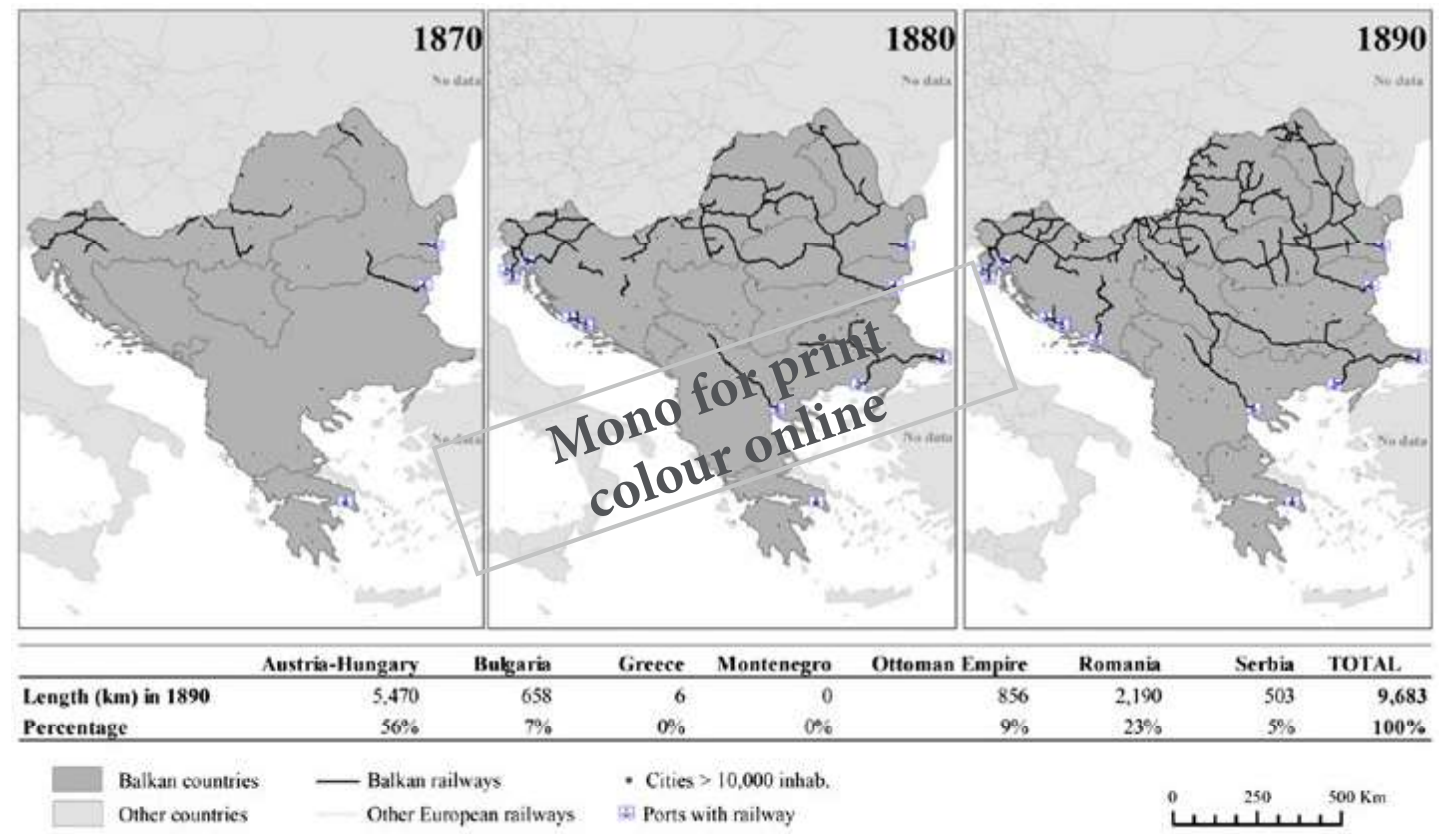

FIGURE 5. THE SPATIAL EVOLUTION OF THE RAILWAY NETWORK AND ITS CONNECTIONS TO THE MAIN PORTS: 1870, 1880, AND 1890. BELOW, TABLE WITH THE LENGTH OF STANDARDGAUGE RAIL TRACK BY COUNTRY IN 1890. Source: HGISE (2015)

Figure 5 shows the spatial spread of the network and how the first railways were constructed in and from the Austro-Hungarian Empire and in the direction of the Black Sea and Aegean Sea ports. In the 1860 s, the network was only just beginning to take shape and was mainly formed by small, isolated, branches. Finally, in the $1880 \mathrm{~s}$, the main connections to the previously mentioned sea ports and the Middle East were completed, which greatly facilitated flows of both goods and people.

This situation changed considerably in the early 1880 s. The 1878 Congress of Berlin not only redrew the political map of this region, but also had repercussions for its railways. The Ottoman Empire had to cede a large part of its European possessions and, as a result, many of the lines constructed by $\mathrm{CO}$ subsequently passed through territories belonging to the newly independent Balkan states. The Congress of Berlin obliged these states to complete the Vienna-Istanbul line and an international commission was set up to decide on, and supervise, its construction. This commission included representatives from the Ottoman Empire, Bulgaria, and Serbia and was chaired by the Austro-Hungarian representative. The resulting line, which came into service in 1888, connected Europe to Asia by rail (Ivanov et al. 2009).

Until the late $1880 \mathrm{~s}$, the Balkan railway network essentially remained in its infancy and continued to be tightly controlled by foreign capital. The routes followed by the main railway lines were therefore decided outside what are now the Balkans: in Vienna and Budapest, and in other Western European capitals, via investment in the Ottoman Empire. The first, and most important lines in the region's railway network were therefore built to serve the interests of powers that are today mainly located outside the Balkan Peninsula (Austria, Hungary, Turkey, and the Great Powers of the nineteenth century). This was confirmed by the data analysed.

Our calculations, based on data on the nationality of the line builders, produced some remarkably clear results (see Figure 6) and revealed that in 1890 more than $85 \%$ of the railway lines in service had been built by foreign (German, French, British, and Austro-Hungarian) companies. 


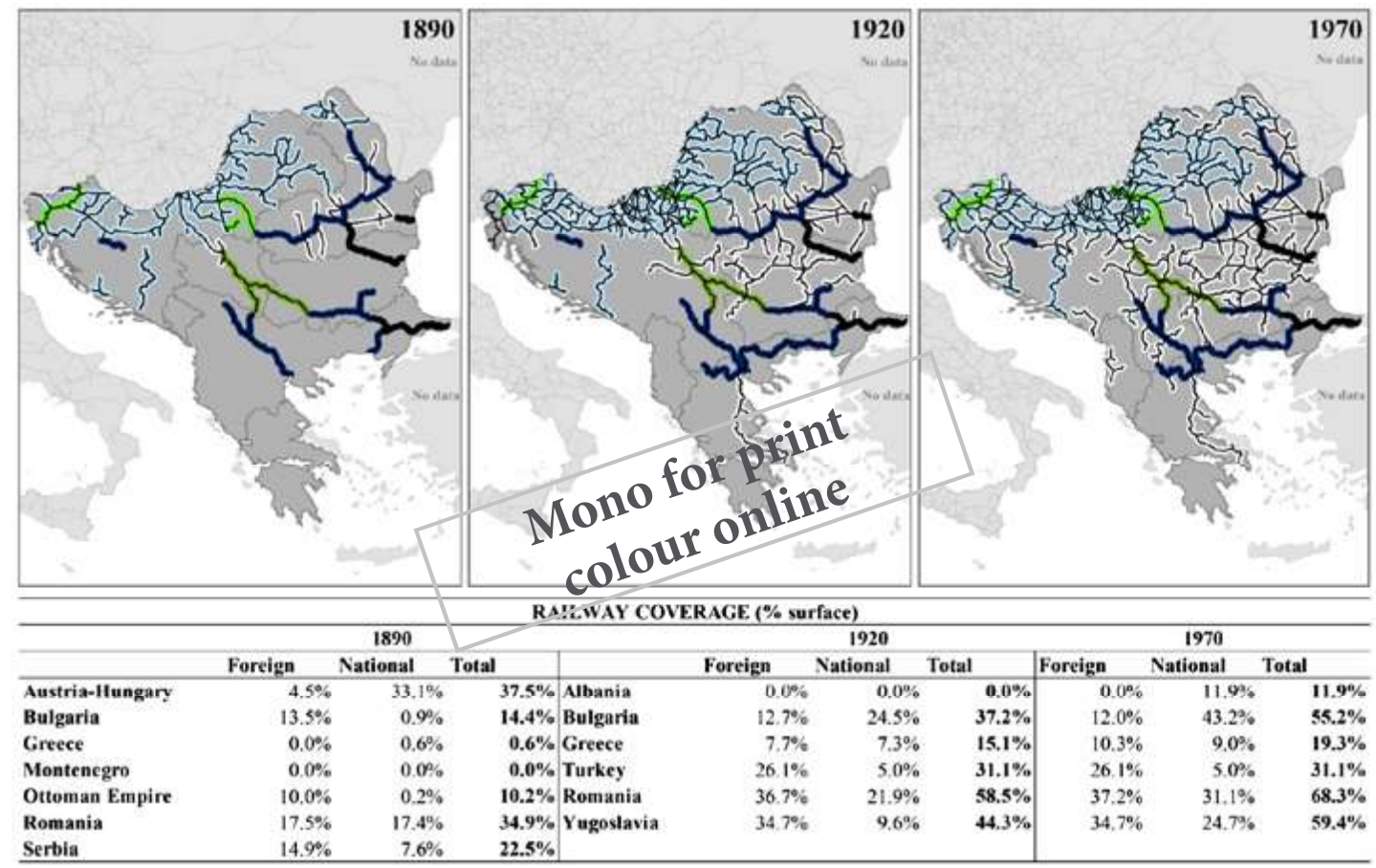

Nationally of the original builder of the railway lines
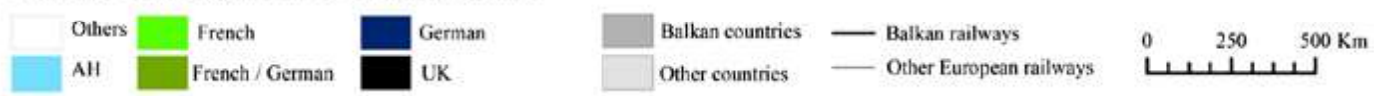

Figure 6. The Territorial Coverage OF THe Railway Network BaSed on SOURCES OF INVESTMENT CAPITAL: 1890, 1920, AND 1970.

Note: The table below provides calculated indices for each country and period and differentiates between the origins of capital investment (foreign or national).

Sources: Own estimation based on: HGISE (2015), Lampe and Marvin (1982), Palairet (1997) for Romania, Greece, Austria-Hungary, and Serbia; Bilmez (2008) for the Ottoman Empire; and Ivanov et al. (2009) for Bulgaria.

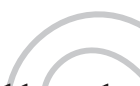

At first glance, and based on the total length of track financed, it would seem that AustriaHungary was the main driving force behind the expansion of the Balkan railway network. However, its interests were mainly confined to within its own borders. As previously stated, the Germans, French, and British were largely responsible for extending the Balkan railway network to the Black and Aegean seas. British entrepreneurs began to construct some of the most important railway lines in the Ottoman Empire and also built several secondary lines during the $1860 \mathrm{~s}$, but after this, lost interest and influence in the Balkan region. British investors sold off their lines when they found that little revenue could be generated from relatively isolated lines connecting the River Danube to the Black Sea; in fact, by the late 1880 s, they had almost completely abandoned the region. French banks promoted several relatively important lines in both the Ottoman and Austro-Hungarian empires, but their investments were concentrated in the 'non-European' territories of the Ottoman Empire.

Overall, the main Balkan railway lines were financed and operated by companies based in Germany and the Habsburg Empire. It is important to bear in mind that the ownership of railway lines sometimes changed hands. For example, in 1890, Baron Hirsch sold CO and $1,260 \mathrm{~km}$ of railway track located in the European part of Turkey to a group of German banks 
led by Deutsche Bank, which further extended German control over rail transport in the region (Hertner 2006). This largely confirms our initial hypothesis relating to the importance of foreign influences in the development of the Balkan railway network.

Figure 6 shows the 'nationality' of each line when it was opened. It is particularly interesting to underline the fact that none of today's Balkan states had full control over the construction of either the first or the main lines that were built in their present territories. The explanation for this is that, in most cases, external interests prevailed over national ones. For example, in Bulgaria, $94 \%$ of the lines that were in service in 1890 had been constructed by foreign investors, as opposed to only $6 \%$ by the Bulgarian state. The same happened in the Ottoman Empire, where almost all the railways were funded and built by foreign entrepreneurs, and in Serbia, where two-thirds of the lines were built by foreign companies.

It should be stressed that our data on investment capital only related to lines directly constructed by foreign investors and that, given their political and economic influences, the Great Powers often dictated the routes followed, with little regard for local interests (Ivanov et al.2009). A particularly clear case of this can be seen in Bulgaria, where the economic and political interests of the country would have benefited from a rail connection between the capital, Sofia, and the major port of Thessaloniki on the Aegean Sea. This line would have also connected the Bulgarian capital to the geographical region of Macedonia, a territory over which Bulgaria had political and economic aspirations. Instead, the country received political and financial pressure from Austro-Hungary to complete the missing parts of the Vienna-Belgrade-Istanbul line in Bulgarian territory; as a result, Sofia's first rail connection to the sea was via a considerably longer line to Istanbul (Stanev et al. 2011).

Furthermore, during the $1890 \mathrm{~s}$, the Bulgarian government faced considerable resistance from the foreign owners of railway lines within its territory to its plans to connect its capital, Sofia, to the Bulgarian Black Sea port of Bourgas (Ivanov et al. 2009). This was not, however, the case in Romania. Although half of its railway network had originally been built by German and Austro-Hungarian consortia, by 1880, it had been taken under state control. The lower percentage of foreign railway construction in Romania could be explained by the fact that the country already controlled a large part of its pre-World War I territories when railway construction started. Although most of Romania's lines were financed by foreign loans, its governments managed to keep a tight control over all the rail routes constructed and to build them according to its own economic, political, social, and military criteria (Popescu 2014). The case of Greece was similar to that of Romania, as the national government planned the railway network and built it with the help of foreign loans; even so, Greece mainly built narrow-gauge lines until 1890 (Zartaloudis et al. 1997).

We measured the extent to which investors exerted effective control over the region's economy by analysing the territorial coverage of its railway network (see Figure 6). Our assumption was that a distance of $10 \mathrm{~km}$ from a railway line would provide an indication of effective territorial coverage, given that this represented a two-hour walk from the railway network. In this way, it was possible to observe two phenomena: the percentage of the surface area of each country with access to the railway network; and, who financed this infrastructure.

Figure 6 shows that in 1890, nearly $5,000 \mathrm{~km}$ of railway effectively covered $38 \%$ of the national territory of Austro-Hungary. The respective coverages in other Balkan countries were $35 \%$ in Romania, $23 \%$ in Serbia, and $14 \%$ in Bulgaria, while in the European part of the Ottoman Empire coverage was only 10\%. The data analysed showed that the AustroHungarian railway network did not provide effective territorial coverage for the whole region 
because the empire did not invest very much outside its own borders. Externally, it only made relatively small, direct investments in Romania. However, we know that the Austro-Hungarian Empire used political and financial channels to influence railway routes constructed outside its own territory and exercised indirect, but effective, control over traffic along the River Danube (Lampe \& Marvin 1982; Palairet 1997). The grip of the Austro-Hungarian Empire on the transport infrastructure of the Balkans was therefore tighter than data suggest.

By 1890, the governments of Romania, Serbia, and Bulgaria had taken effective control over the construction of new railway lines in their respective territories, seeing this as a means to strengthen their independence. Even so, some of the previously built lines remained under foreign control. This was particularly true in Bulgaria, where the struggle for control over the lines built by $\mathrm{CO}$ was a source of great political tension and financial instability throughout the late 1890s (Ivanov et al. 2009).

Given the need for credit to finance the construction of the Balkan railway network, as previously mentioned, foreign interests continued to exert considerable influence in the region for some time. As a result, even when the Great Powers no longer had direct control over railway construction, the major investments required for this infrastructure kept the different Balkan governments dependent on European banks and governments. In fact, most of the new Balkan states ran into financial difficulties within a few decades of acquiring political independence. Most notably, in 1898, an International Finance Commission (Commission

20 Internationale Financière de la Grèce) forced Greece to accept the Commission's financial control of its revenue in order to pay off its outstanding debts (Levandis 1944).

What was new was the fact that the construction of new railway infrastructure now followed territorial guidelines laid down by these new nation states. All these developments had an important impact on the spatial evolution of the railway network in the Balkans. Amidst their struggles for influence in the region, the Great Powers designed and developed a railway system that was connected to the European network. However, once the main international lines had been completed and most of the new Balkan states had been constituted, these newly independent states followed the dictates of their own internal requirements when further developing the Balkan rail network. As a result, the process of Balkan rail service integration soon stagnated or went into decline.

\section{The 'Balkanisation' of the railway network after World War I}

After World War I, the Balkan railways continued to expand, as reflected by the increase in territorial coverage observed during the period between 1920 and 1970 (see Figure 6). However, the war also marked the start of a new railway dynamic which, according to our data, was characterised by the gradual breaking up of the overall railway network in this region. This 'Balkanisation' started, in a metaphorical sense, with the political fragmentation of the Balkans, which hampered the further integration of the railway network. It then continued in a more literal sense, as the newly emerged states assumed full control over the railways in their respective territories.

The Balkan Wars and World War I, and the resulting political divisions, gave rise to tensions which had a lasting impact on international rail connections in the region. The wars caused great distrust between Bulgaria, which was defeated, and Greece, Romania, and the new state formation Yugoslavia, who were among the victors of the war; and this tension was to 
dominate political and economic relations in the Balkans throughout the interwar period. As a result, connections between neighbouring states remained relatively underdeveloped, with Bulgaria's central position adversely affecting the overall structure of the Balkan railway network. More importantly, the Balkans was one of the regions of Europe most affected by the territorial changes that occurred during the 1910s. The new borders cut across existing railway routes, which had a transforming impact on the different networks. Some former main lines were relegated to secondary status, while other, originally less important, routes were upgraded. This new territorial reality called for the reshaping of the railway network in each state and also that of the region as a whole. As a result, governments had to take control of the different networks, nationalise private lines, and plan future transport development (Howkins 1999).

The new model for planning and constructing railway infrastructure was based on improving the internal articulation of each national transport system. As a result, the data studied revealed two clear trends. From World War I onwards, direct foreign investment was replaced by local capital, while the size of the different national networks increased considerably during the period 1910-1950, boosted by the construction of more lines for internal use.

Figure 7 shows that from 1910 onwards, the total length of railway track promoted by foreign capital stagnated: the era of foreign investment had effectively come to an end. Moreover, some of the lines originally built as a result of foreign initiatives closed after 1918.

Figure 8 shows that in 2000, almost a century after the fall of the Austro-Hungarian Empire, the length of railway track originally constructed or financed by Austria-Hungary remained very significant. Even so, it remained largely restricted to territories that had originally been controlled by the empire. As noted in a previous section, in the rest of the Balkan region, French, British, and, in particular, German, capital had constructed the majority of the most internationally important lines in the nineteenth century. This clearly shows how nineteenthcentury railways were primarily constructed to boost international trade.

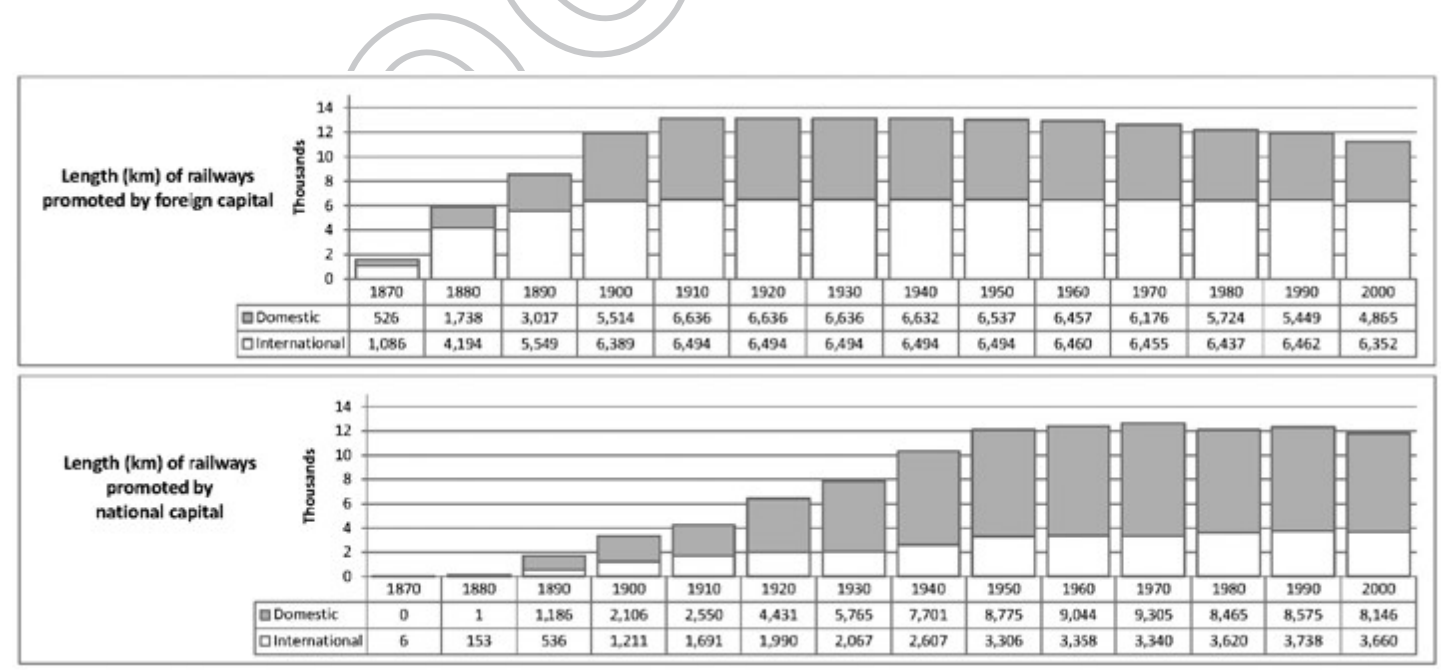

FIGURE 7. THE EVOLUTION OF THE RAILWAY NETWORK ACCORDING TO ITS HIERARCHY (INTERNATIONAL OR DOMESTIC) AND THE ORIGINS OF ITS CAPITAL INVESTMENT (FOREIGN OR NATIONAL).

Sources: Own estimation based on: HGISE (2015), Lampe and Marvin (1982), Palairet (1997) for Romania, Greece, Austria-Hungary, and Serbia; Bilmez (2008) for the Ottoman Empire; and Ivanov et al. (2009) for Bulgaria. 


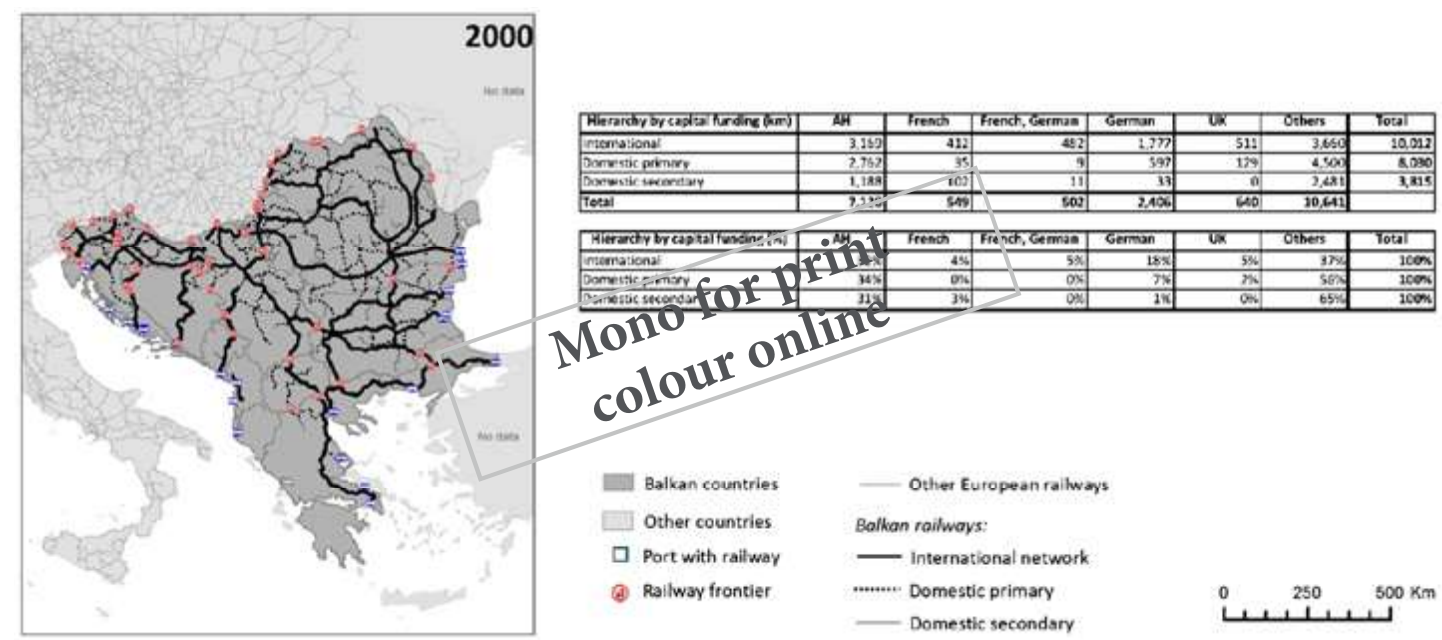

FIGURE 8. THE RAILWAY NETWORK HIERARCHY IN 2000, IDENTIFYING INTERNATIONAL, PRIMARY, AND SECONDARY LINES.

Note: The table on the right includes calculated indices based on line hierarchy and the nationality of the capital investment that funded their construction.

Source: Own estimation based on HGISE (2015).

The table in Figure 8 shows that only $37 \%$ of the international lines in the Balkans were built as a result of local initiatives, whereas for primary and secondary lines, the respective values were $56 \%$ and $65 \%$. Between 1910 and 1950 , the growth of the region's railway network was predominantly attributable to the construction of lines for internal use. During this period, the priority for those planning this infrastructure was apparently to develop their country's own domestic networks.

The data analysed confirmed that the lines constructed during the interwar period only had an impact at the national level and that national railway networks were mainly used to reinforce the internal sovereignty of states. It is evident that this happened at the expense of cross-border connections that might have improved the economic integration of this politically fragmented region. The only signs of efforts to develop international trade could be seen in the construction of railway links to ports. Even so, these lines tended not to extend beyond national borders. The new port connections therefore promoted trade between a given country and the rest of the world, without serving to improve economic relations between neighbouring countries.

In order to quantify and analyse the connectivity between states, we calculated the number of border crossings with railway connections. These data showed the evolution of rail connections between the different Balkan states from 1920 until the maximum expansion of the Balkan railway network, in 1970. Despite the uniform growth of the rail network in the Western Balkans, no new connections were established between Yugoslavia and the states along its southeastern borders. Within Yugoslavia, existing lines were reinforced by linking up internal branch lines and making new connections to ports, but the international connectivity of the network hardly improved. In the north, the dissolution of Austria-Hungary resulted in the closure of a number of lines and in a reduction in the number of border crossings.

In the Eastern Balkans, Bulgaria developed an internal network based on two main railway lines that crossed the state and had branches leading out towards, but without actually reaching, its borders. As a result, by 1920, Bulgaria only had international railway connections with 
Turkey and Serbia. Some secondary lines did cross Bulgaria's borders with Romania and Greece, but they did not connect major urban centres in either state. In fact, Bulgaria and Romania were not connected by a main line until the 1950s. It is surprising that there had not been any previous connection with Bucharest, particularly as Romania had needed, and sought, a connection with Istanbul since the late nineteenth century. A similar strategic link between Thessaloniki, in Greece, and Sofia was only completed in 1965. In fact, even in 2017, Bulgaria has no railway connection with its historically and culturally closest neighbour, Macedonia.

At its maximum extension, in the 1970s, the Balkan railway network had 55 cross-border connections (see Figure 9), only four connections more than half a century earlier. Naturally, there had been line openings and closures since 1920; however, the fact that there were more lines, but that the number of border crossings had changed only moderately, suggests a significant lack of integrated railway planning.

The lack of integration of the network was further confirmed by the analysis of another variable: an index called the 'route factor'. This relates the distance by rail between two nodes to the straight-line distance between the same two points and allows us to evaluate the evolution of the spatial efficiency of a railway system. A ratio of close to 1.0 indicates a direct and efficient connection. Values of up to 1.5 are considered less efficient. Small deviations in these values could be the result of socio-political or topographical factors. In our opinion, terrain would not normally be the main reason for ratios of above 1.5, and ratios of between 1.5 and 2.0 would probably show that the lines in question had not been planned to provide an optimal service between the two points connected. Finally, indices of greater than 2.0 would show that the lines had not been designed to provide direct connections, but were the result of connections with other neighbouring settlements.

The data clearly suggested the inefficiency of the network. Table 1 shows that in 1920, a number of urban centres, including Tirana, Sarajevo, and Podgorica, either did not form part of the Balkan railway network or did not have adequate connections with neighbouring capitals and, as a result, remained isolated from the other cities. The mountainous terrain of the Western

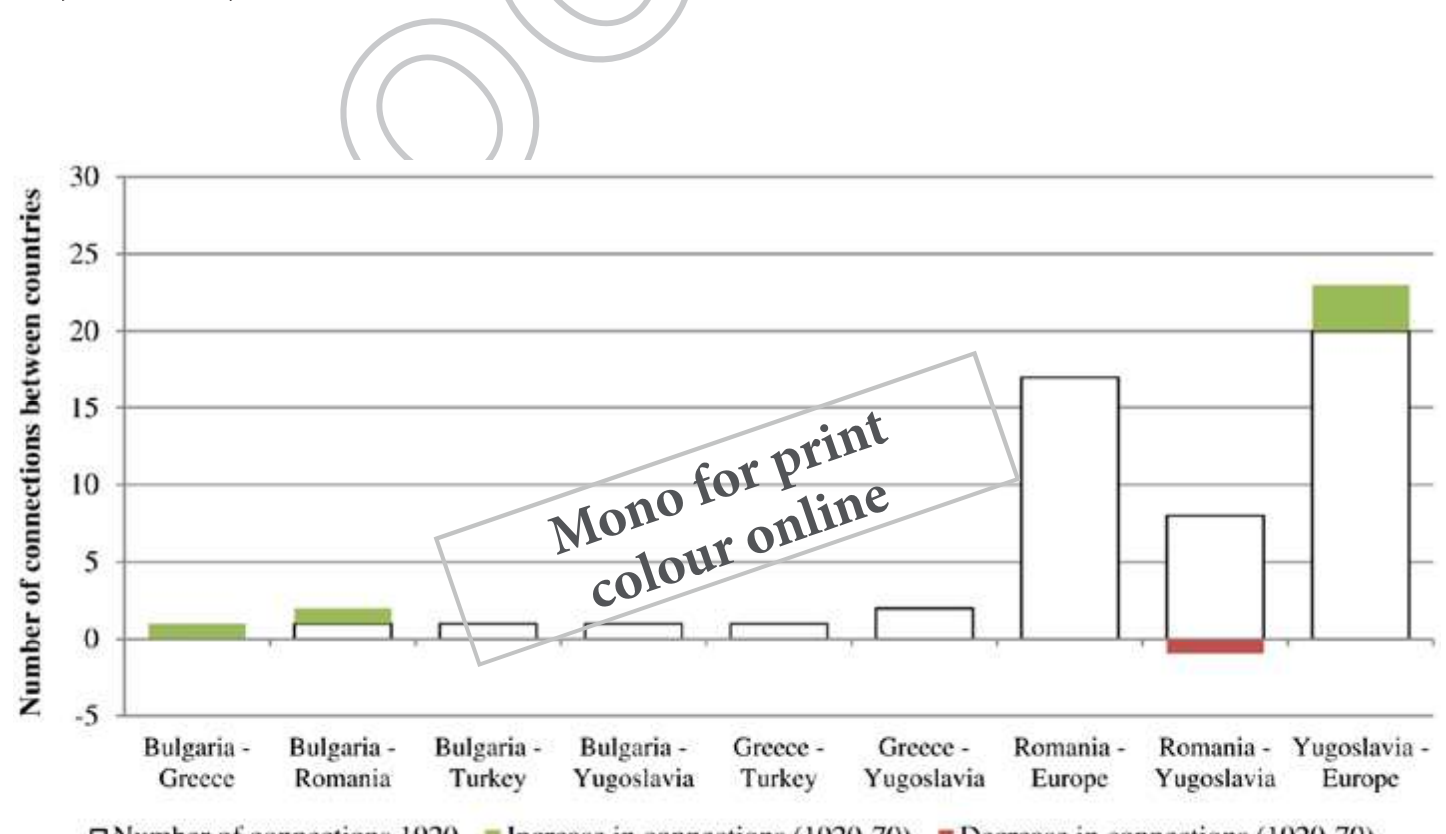

$\square$ Number of connections $1920=$ Increase in connections (1920-70) $\equiv$ Decrease in connections (1920-70)

FIGURE 9. EVOlution of THE NuMBER of RAIL BORDER CROSSINGS: 1920 AND 1970. Source: Own estimation based on HGISE (2015). 


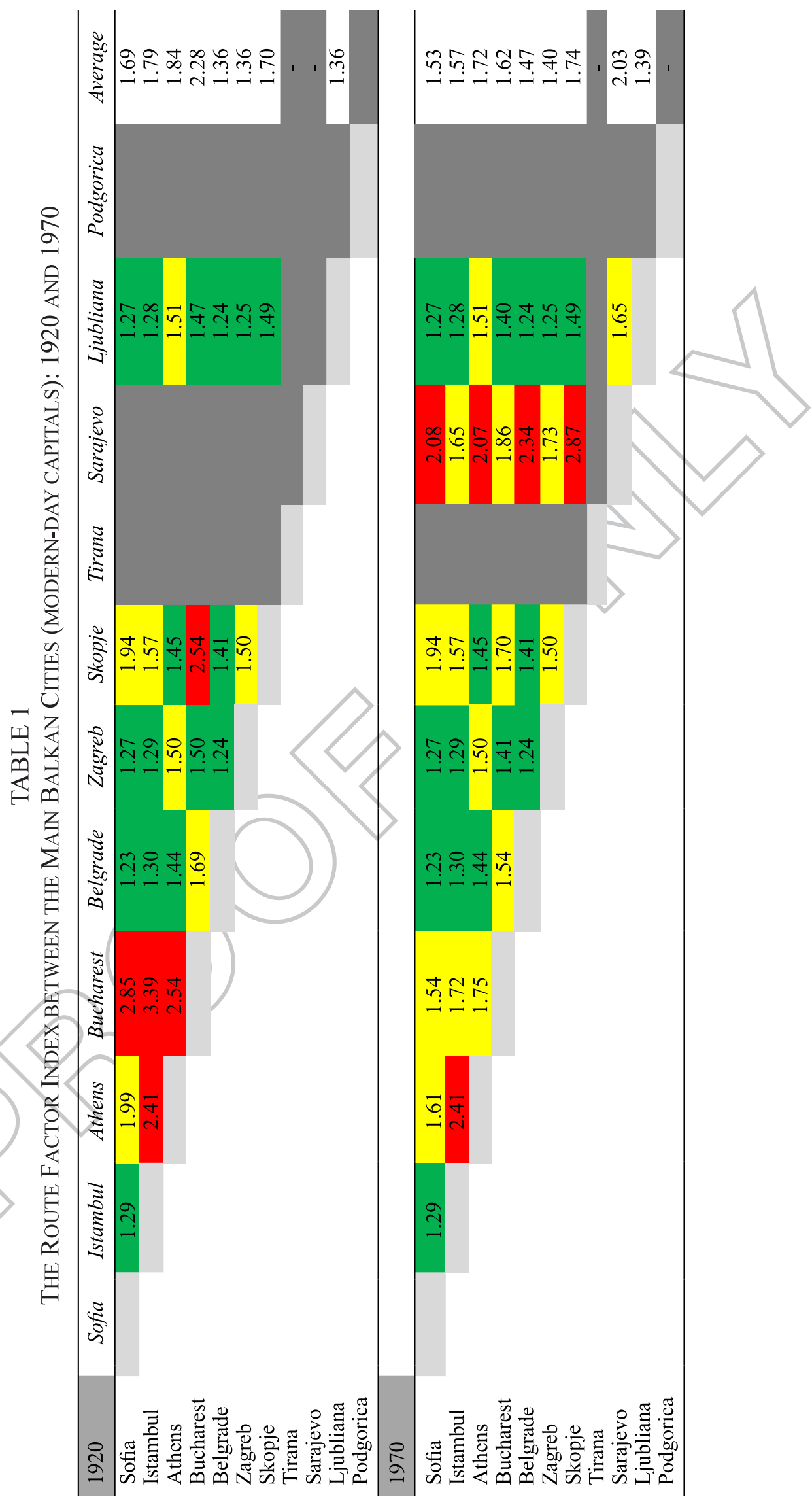


Balkans has certainly played a major role in these three cases. Other capitals that did not have adequate connections with neighbouring capitals included Athens, with Sofia and Istanbul; Bucharest with Sofia, Skopje, Istanbul, and Athens; and Sofia with Skopje. As well as lacking these links, some of the existing rail connections did not follow the optimum route. Thus, the connections from Belgrade to Athens and Bucharest; Zagreb to Athens and Bucharest; Skopje to Istanbul, Athens, Belgrade, and Zagreb; and Ljubljana to Athens, Bucharest, and Skopje all had route index values of up to 1.5. The poor results for Athens can be explained by the geographic location of the Greek capital. In most cases, a straight line connecting Athens to another major urban centre would pass through the sea and a straight line rail connection would therefore be physically impossible. In other cases, however, direct connections between capitals were avoided for political and military reasons.

By 1970, the level of connectivity had improved, but not significantly. The construction of the Ruse-Giurgiu Bridge over the River Danube improved the accessibility of Bucharest, which became much better connected with other major centres in the southern part of the region. The links between Sarajevo and other important cities in Yugoslavia and the rest of the Balkans also became more direct and efficient. Even so, the difficult terrain continued to limit accessibility and therefore its route index value often remained above 2.0.

The different variables used confirmed the obstacles encountered by the Balkan states when trying to integrate their railway systems. Political hostilities and difficult terrain partially explain the relatively underdeveloped international railway connections between the different Balkan states. An additional explanation might be that some of the Balkan capitals were not connected because there was little economic demand for this; they made similar products for export, hence there would only have been limited complementarity. Whatever the case, this only serves to confirm our hypothesis regarding the lack of economic integration between the Balkan states during this period.

Most of the-relatively few -international infrastructural connections were built during the 1940s and 1950s and - in line with our hypothesis - could largely be attributed to the influence of a new foreign power in the region: the USSR. The Soviet Union promoted cooperation between communist states in the Balkans; at the beginning of the Cold War, these included Bulgaria, Romania, Yugoslavia, and Albania. Although there was later a degree of political conflict between Yugoslavia and the Soviet Union (the 1948 Tito-Stalin split), during this period trade between Romania, Bulgaria, Yugoslavia, and the rest of the Eastern Bloc increased significantly, which called for better transport connections in the Balkans (Ehrlich 1985). The USSR provided technical and political support for some of the most important infrastructural projects undertaken in the region, such as the construction of the Iron Gate power plant on the River Danube (a joint venture between Yugoslavia and Romania). In the specific case of railway infrastructure, one of the most notable improvements was a bridge over the River Danube. Completed in 1954, this finally connected Romania and Bulgaria, thereby considerably improving rail connections between Bucharest and the rest of the Balkans. As well as benefiting Romania and Bulgaria, the bridge also enhanced accessibility to the region for the USSR, which became a major trading partner for both countries during the Cold War period (Lampe 1986). A second bridge was later built over the River Danube between Romania and Bulgaria; this opened in 2013 and received major political and financial backing from the European Union. Once again, however, it could perhaps be argued that improvements in the previously limited integration of the Balkan transport system after World War II were 
largely imposed on the Balkan states by a foreign power, rather than being the product of direct collaboration between them.

World War II had an enormous political and socioeconomic impact on Europe, and on the Balkans in particular. Basic infrastructure suffered considerable damage and after the war, the railways were in a dire need of repair. However, in contrast to World War I, World War II had only a limited impact on the political map of the region, as the number of states and their borders remained relatively stable. As a result, we do not consider World War II as a watershed in the development of the railway network in the region, as it did not have a substantial impact on the construction of new lines or on the closing of existing ones. However, although the expansion of the network continued, postwar efforts focused more on repairing the existing lines than on constructing new ones. This was especially true in Yugoslavia and Greece, where railway infrastructure suffered major damage during the war. Moreover, given the stability of political boundaries, there was no need to reorganise existing lines on the scale made necessary by the political transformations caused by World War I.

Furthermore, although after World War II, buses and cars gradually replaced trains as the main form of land transport throughout Western Europe and public investment shifted towards roads, in the communist-controlled states of Eastern Europe, the decline of rail transport would be postponed for several decades (see Figure 4). This was mainly attributable to continued public use of the railway sector, increasing trade, industrial activity, and the relative underdevelopment of the private transport sector in these countries.

\section{The stagnation and decline of the Balkan rail network}

In the Balkans, railways maintained their importance until the 1990s, but since the collapse of the Eastern Bloc there has been a considerable increase in car ownership and in the use of bus transport, both of which have taken a lot of traffic away from the railways (Thompson 2001). That said, it should be underlined that the expansion of the railway network in the region had already effectively come to a halt by the end of the $1960 \mathrm{~s}$, and that most of the investment made in railways thereafter focused on improving the existing network (doubling tracks and electrifying lines) rather than on expanding it.

The stagnation of the 1960s and 1970s had turned into decline by the 1980s. As a result, from the 1950s onwards, the total length of railway track in service began to decline, albeit only slightly at first. This was particularly noticeable in Romania and Yugoslavia (see Figure 10). This reduction in the length of the network could also, at least in part, have been due to an increase in its efficiency. To test whether this was the case, we checked if the lines that had been closed were replaced by shorter routes. It was also possible that a significant decline in rail transport in one particular state could have affected the result for the whole Balkan network; we therefore checked whether line and station closures were generalised or only occurred in particular countries.

Figure 10 provides data on the opening and closure of lines in different countries between 1920 and 1990. In Turkey and Bulgaria, there was no clear evidence of any reduction: there was no change in the number of lines that were open in European Turkey, while in Bulgaria, new lines opened without old ones closing. In Romania and Greece, some services closed, but the total number did not significantly change. In Greece, peak rail coverage was reached in 1970, after which it began to fall. In 1971, the different Greek railway companies were amalgamated into a single unit: the Hellenic Railways Organisation (Organismos Sidirodromon Ellados) and 

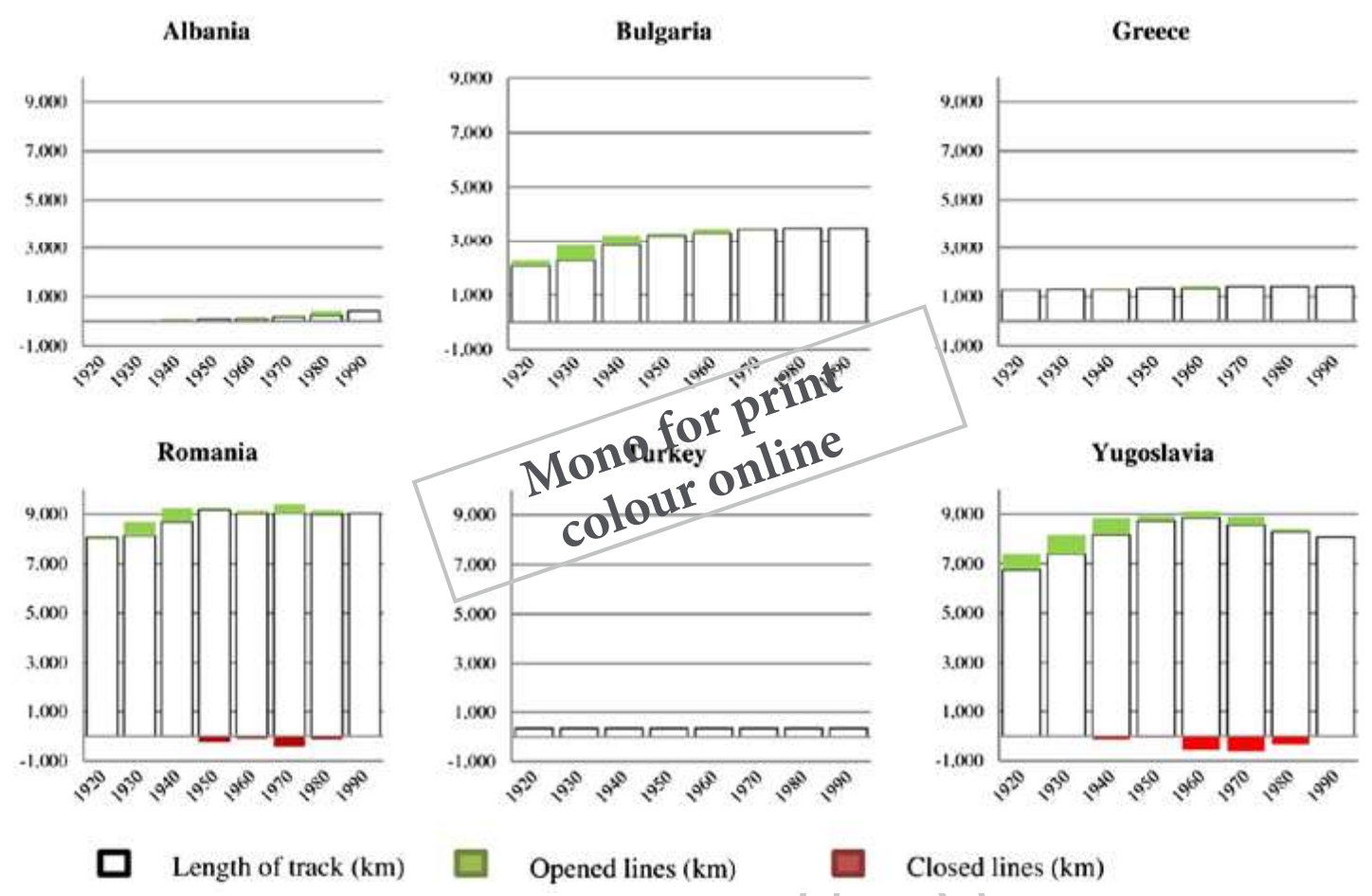

FIGURE 10. EVOLUTION OF THE LENGTH OF NATIONAL RAILWAY) NETWORKS By COUNTRY, IDENTIFYING THE OPENING/CLOSURE OF LINES: 1920-1990.

Source: Own estimation based on HGISE (2015).

this reorganisation was accompanied by the closure of many narrow-gauge branch lines. During the second half of the twentieth century, the number of line openings and closures in Romania was very high, with the former almost compensating for the latter. This could be understood as a re-articulation of the network with the goal of adjusting to the territorial changes that had followed World War I but which had not been remedied in the 1920s and 1930s. Whatever its cause, this was the only such case observed in any of the countries analysed.

Finally, in Yugoslavia, there was a steady reduction in the extent of the railway network from 1960 onwards. Mainly as a result of its Austro-Hungarian heritage, during the interwar period this country had the densest rail network in the Balkans. However, in order to serve the political and economic interests of the new state of Yugoslavia, the rail network required significant reconstruction and improvement. In fact, more railway construction took place in Yugoslavia after 1945 than in any other state in the region.

Even so, the total number of lines that closed during this period almost tripled the number of new ones that opened. It could therefore be argued that the gradual decline of rail transport in

15 Yugoslavia was accompanied by a major readjustment in the country's rail infrastructure. This decline further intensified in the 1990s. War and the subsequent dissolution of the Yugoslav state resulted in the destruction of part of its rail infrastructure and in the fragmentation of its rail network, with new borders cutting across a number of existing railway lines. These problems were exacerbated by the international trade embargo placed on the resulting state of Serbia and Montenegro and by a fall in passenger traffic due to a rise in private car ownership. ${ }^{3}$

${ }^{3}$ The countries of former Yugoslavia experienced a seven times decrease of passenger rail traffic between 1988 and 1996; and a 40\% increase of private car ownership between 1988 and 1998, according to Thompson (2001). 

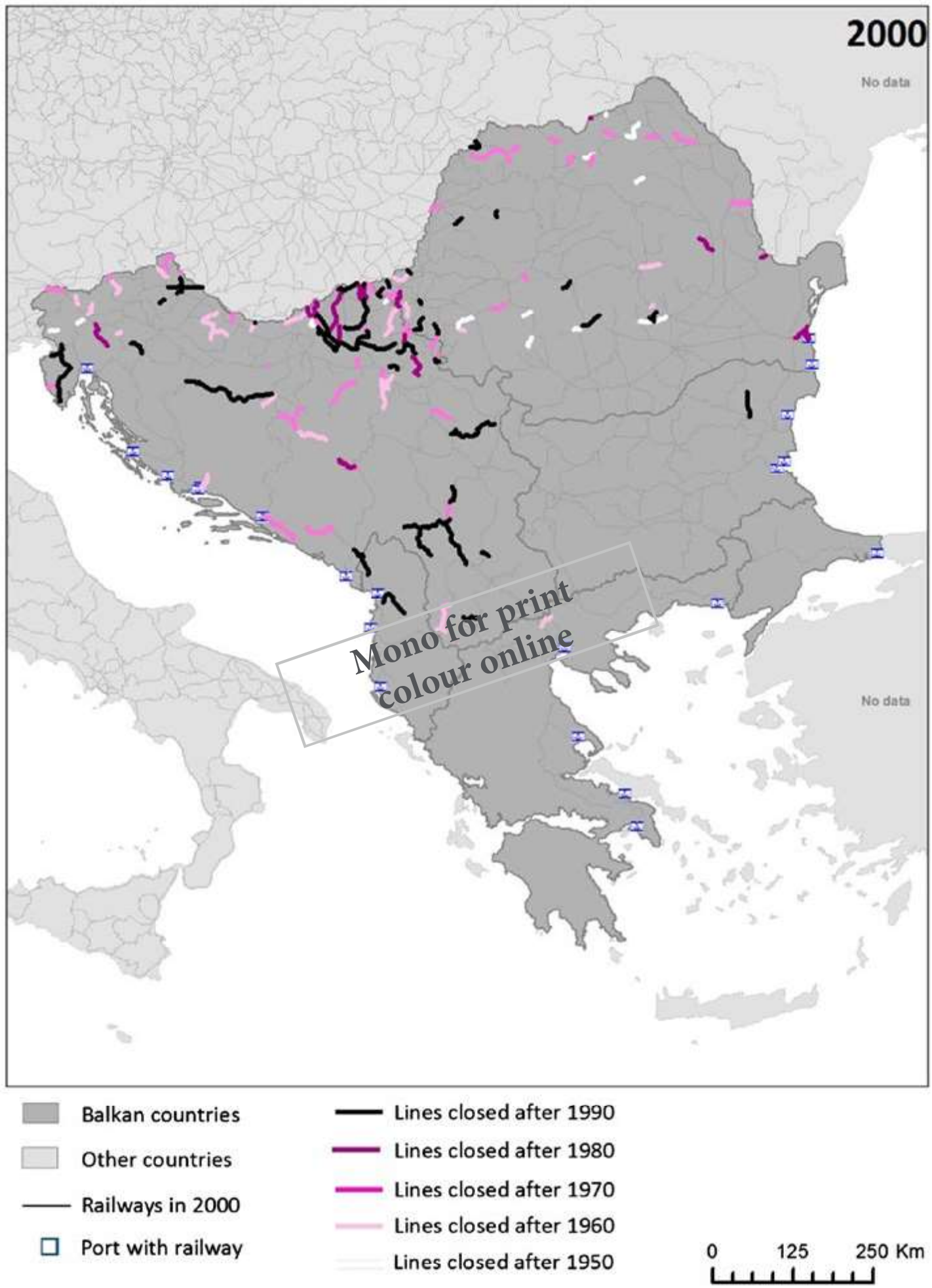

FIGURE 11. ClosURES OF RAILWAY LINES, 1950-2000.

Source: Own estimation based on HGISE (2015).

There was, however, one notable exception to the overall pattern of decline: in Albania, the development of the rail network occurred very late and did not reach its peak until 1990. This state only opened its first standard-gauge public railway in 1947. However, the totalitarian 
regime under Enver Hoxha decided to extensively promote rail travel. This process was aided by an effective prohibition on the use of private transport in Albania. However, the evolution of the Albanian railway network took place in isolation from that of the rest of the Balkans and it was not until the 1980s that a rail connection was established with another country (Yugoslavia); this was soon cut off following the outbreak of war in Bosnia \& Hercegovina in 1992. Furthermore, after the collapse of the totalitarian regime, there has been a substantial increase in private car ownership and bus usage. This started the decline of the Albanian railway network during the $1990 \mathrm{~s}$, with this trend continuing throughout the following decade.

Generally speaking, it could be said that the Balkan railway network entered a period of stagnation during the last three decades of the Cold War period. Figure 11 shows that most of the lines that closed during the second half of the twentieth century were located in territories that had previously belonged to the Austro-Hungarian Empire and were mainly in Yugoslavia or Romania. In contrast, relatively few lines were closed in Bulgaria, Greece, or Albania, and most of the railway lines in the European part of Turkey remained in service.

After 1990, the dissolution of Yugoslavia and the collapse of the Soviet political and economic bloc had a significant impact on the Balkan railways. Although the overall length of track declined only moderately, freight and, to a lesser extent, passenger traffic dropped considerably in all the Balkan states after 1989 (Mitchell 1998). As already mentioned, by this time the railway was no longer the main means of transport in the region; thus, beyond this point we can no longer use the railways as a proxy for economic integration in the Balkans.

\section{Conclusions}

Our objective was to determine the relationship between the autonomy of the Balkan countries and the integration of their railway networks during the period between the construction of the first railway lines in the region in the mid-nineteenth century and the end of the twentieth century. This focus on the railway network also proved useful in revealing a more general issue: for 150 years economic integration in the Balkans was strongly related to the level of the region's political and economic dependence on the outside world.

We have identified three distinctly different periods in the evolution of the Balkan railway network. The first Balkan railway lines were only slightly affected by the limitations imposed by national borders. This was firstly because there were fewer borders during this period; and secondly, because of the limited political and economic autonomy of regional governments. During the first period (1840s-1880s), the interests of Austria-Hungary, Germany, France, the UK, and the Ottoman Empire were the main driving forces behind the development of the Balkan railway network. However, these external promoters of the Balkan railways created a network of predominantly long-distance lines with relatively few, if any, branch lines. These first lines, which determined the general structure of today's Balkan railway network, initially mainly served the interests of states that either no longer exist or which were located outside or on the periphery of the region. The result was the formation of a network that did not provide adequate support for local economies. During the nineteenth century, it largely served the interests of foreign commercial and political powers.

In the second period, which began towards the end of the nineteenth century and reached its peak after World War I, the national interests of the independent Balkan states prevailed. The political fragmentation of the region limited the development of a more integrated Balkan 
railway network as domestic railway systems expanded, for the most part, in isolation. The density of these networks increased, but the connectivity between the states in the region remained relatively limited. Connectivity did slightly improve during the first decades of the Cold War, when another outside power, the USSR, promoted cooperation between the Balkan states that were under communist regimes. However, border-related tensions generally remained an obstacle and prevented the development of a more efficient network. The expansion of the railway network continued and by 1960, the gap between the Balkans and the rest of Europe had been considerably reduced.

After the 1960s, following an increase in the availability of alternative means of transport, such as private cars, public buses, and trucks, the growth of the railway network came to a halt and then during the 1980s entered into a period of decline, with a critical number of lines closing. This largely explains the current state of the Balkan rail network, which is moribund.

Our initial hypothesis was therefore largely confirmed: during the nineteenth century, guided by the Great Powers, railway construction boosted the economic integration of the Balkans and connected the region with the rest of Europe; however, in the twentieth century, the independent Balkan states failed to integrate their respective infrastructures. In a somewhat ironic twist, during the twentieth century, more new cross-border international railway lines were created as a result of changes to previous international borders than as a result of new lines being specifically planned and built to cross pre-existing borders. The former might have been expected to promote the integration of the region, but the political fragmentation that resulted effectively ushered in the disintegration of the railway network.

These results lead us to suggest that, in the future, the expansion of European Union membership amongst the states in this region should help to promote the further integration of railway infrastructure in Southeast Europe, following the model, highlighted in the current study, of external actors and influences promoting greater transnational integration.

Kaloyan Stanev, Department of Economics and Business, Pompeu Fabra University, Ramon Trias Fargas, 25-27, 08005 Barcelona, Spain. Email: kaloyan.stanev@gmail.com. AQ1 (iD) http://orcid.org/0000-0001-8176-5686

Jordi MArTí-HenneBerg, University of Lleida, Plaça Victor Siurana, 1 25003, Lleida, Spain. AQ2 Email: marti.henneberg@geosoc.udl.es. (D) http://orcid.org/0000-0001-7651-2465

\section{References}

Alvarez, E., Franch, X. \& Martí-Henneberg, J. (2013) 'Evolution of the Territorial Coverage of the Railway Network and its Influence on Population Growth: The Case of England and Wales, 1871-1931', Historical Methods: A Journal of Quantitative and Interdisciplinary History, 46, 3.

Berend, I. \& Ranki, G. (1969) Kozep-Kelet-Europa gazdasagi fejlodese a 19-20. szazadban (Budapest, Közgazdasági és Jogi Könyvkiadó).

Bilmez, B. (2008) 'European Investments in the Ottoman railways, 1850-1914', in Roth, R. \& Dinhobl, G. (eds) Across the Borders: Financing the world's Railways in the Nineteenth and Twentieth Centuries (Aldershot, Ashgate).

Blunden, W. R. (1971) The Land-use/Transport System. Analysis and Synthesis (Oxford, Pergamon Press). 
Bouwman, M. E. \& Moll, H. C. (2002) 'Environmental Analyses of Land Transportation Systems in The Netherlands', Transportation Research Part D: Transport and Environment, 7, 5.

Caruana-Galizia, P. \& Martí-Henneberg, J. (2013) 'European Regional Railways and Real Income, 1870-1910: a Preliminary Report', Scandinavian Economic History Review, 61, 2.

Chester, K. (2006) The Narrow Gauge Railways of Bosnia-Hercegovina (Malmö, Stenvalls).

Deyanov, D. (2005) Zhelezopatnata mrezha v Bulgaria 1866-1975 (Sofia, Bulhouse).

Donaldson, D. \& Hornbeck, R. (2013) Railroads and American Economic Growth: 'A Market Access' Approach, NBER working paper 19213 (Cambridge, MA, National Bureau of Economic Research), available at: http://www.nber.org/papers/w19213, accessed 2 November 2017.

Duranton, G. \& Turner, M. A. (2012) 'Urban growth and transportation', The Review of Economic Studies, 79, 4. Dupuy, G. (1991) L'Urbanisme des Reseaux, théories et méthodes (Paris, A. Colins).

Ehrlich, E. (1985) 'Infrastructure', in Kaser, M. C. \& Radice, E. A. (eds) The Economic History of Eastern Europe 1919-1975 (Oxford, Clarendon Press).

Franch, X., Morillas-Torné, M. \& Martí-Henneberg, J. (2013) 'Railways as a Factor of Change in the Distribution of Population in Spain, 1900-1970', Historical Methods: A Journal of Quantitative and Interdisciplinary History, 46, 3.

Gastner, M. T. \& Newman, M. E. (2006) 'Shape and Efficiency in Spatial Distribution Networks', Journal of Statistical Mechanics: Theory and Experiment, 1.

Hagget, P. (1977) Locational Analysis in Human Geography (London, Edward Arnold).

Hertner, P. (2006) 'The Balkan Railways, International Capital and Banking from the end of the 19th Century until the Outbreak of the First World War', Bulgarian National Bank Discussion Papers, 53.

Howkins, T. J. (1999) 'The Adjustment of International Rail Passenger Services to New State Boundaries-The Eastern Marchlands of Europe 1918-39', Journal of Transport Geography, 7, 2.

Ivanov, M., Todorov, T. \& Vachkov, D. (2009) Istoria na vynshnia dyrzhaven dalg an Bylgaria (1878-1990), (History of the foreign public debt of Bulgaria 1878-1990) (Sofia, Bulgarian National Bank).

Jelavich, C. \& Jelavich, B. (1977) The establishment of the Balkan national states: 1804-1920, Vol. 8 (Washington, DC, University of Washington Press).

Kansky, K. \& Danscoine, P. (1989) 'Measures of network structure', Flux, 5, 1.

Keller, W. \& Shiue, C. H. (2008) Institutions, technology, and trade, NBER working paper 13913 (Cambridge, MA, National Bureau of Economic Research), available at: http://www.nber.org/papers/w13913, accessed 1 November 2017.

Kostov, A. (1995) 'Trade and Navigation on the Lower Danube: Romania and Bulgaria 1880-1912', Inland Navigation and Economic Development in Nineteenth-Century Europe, 39.

Kraus, F., Flora, P., Martí-Henneberg, J. \& Schweikart, J. (eds) (2018) European Regions. The Territorial Structure of Europe, 1870-2000 (London, Palgrave Macmillan).

Lampe, J. R. (1975) 'Varieties of Unsuccessful Industrialization: The Balkan States before 1914', Journal of Economic History, 35, 1.

Lampe, J. R. (1986) The Bulgarian economy in the twentieth century (London \& Sydney, Croom Helm).

Lampe, J. R. \& Marvin, J.(1982) Balkan Economic History, 1550-1950: From Imperial Borderlands to Developing Nations (Bloomington, IN, Indiana University Press).

Levandis, J. A. (1944) The Greek Foreign Debt and the Great Powers, 1821-1898 (New York, NY, Columbia University Press).

Martí-Henneberg, J. (2013) 'European Integration and National Models for Railway Networks (1840-2010)', Journal of Transport Geography, 26.

McMeekin, S. (2010) The Berlin-Baghdad express: the Ottoman Empire and Germany's bid for world power (Cambridge, MA, Harvard University Press).

Mitchell, B. (ed.) (1998) International historical statistics: Europe 1750-1993 (London, Macmillan Reference and New York, NY, Stockton Press).

Mojica, L. \& Martí-Henneberg, J. (2011) 'Railways and Population Distribution: France, Spain, and Portugal, 1870-2000', Journal of Interdisciplinary History, 42, 1.

Morillas-Torné, M. (2012) 'Creation of a Geo-Spatial Database to Analyse Railways in Europe (1830-2010). A Historical GIS Approach', Journal of Geographic Information System, 4.

Nikova, E. (2007) 'Roads Connecting, Roads: Infrastructure in South East Europe', Etudes Balkaniques, 1.

O'Brien, P. (1983) Railways and the economic development of Western Europe, 1830-1914 (London, Macmillan).

Organ, J. (2008) Romania \& Bulgaria Narrow Gauge. Narrow Gauge Branch Lines series (Midhurst, Middleton Press).

Palairet, M. (1997) The Balkan Economies c. 1800-1914 Evolution without Development (Cambridge, Cambridge University Press).

Pamuk, Ş. (1987) The Ottoman Empire and European capitalism, 1820-1913: Trade, Investment, And Production (Cambridge, Cambridge University Press). 
Popescu, T. (2014) The Romanian Railway Project (1842-1916) (Bucharest, Simetria).

Purcar, C. (2010) 'On the Wrong Side of the Track: Railways as Urban Boundaries in the Towns of the First Transylvanian Railway', Urban History, 37, 1.

Rostov, W. (1953) The Process of Economic Growth (Oxford, Oxford University Press)

Stanev, K. (2011) 'Railways, Regions and the Urban Network in the Balkans during a Century of Political Transformations 1900-2000', Etudes Balkaniques, 47, 1.

Stanev, K. (2013) 'A Historical GIS Approach to Studying the Evolution of the Railway and Urban Networks: The Balkans, 1870-2001', Historical Methods, 46, 3.

Stanev, K., Martí-Henneberg, J. \& Ivanov, M. (2011) 'Regional Transformations of a State under Construction: Bulgaria, 1878-2002', Journal of Interdisciplinary History, 42, 1.

Thompson, L. (2001) Railways in Eastern Europe (Cambridge, OECD Round Table 120).

Todorova, M. N. (1997) Imagining the Balkans (New York, Oxford University Press).

Turnock, D. (1979) 'The Romanian Railway Debate: A Theme in Political Geography', Journal of Transport History, 5.

Turnock, D. (1986) The Romanian Economy in the Twentieth Century (New York, NY, St. Martin's Press).

Turnock, D. (1989) Eastern Europe: An Economic and Political Geography (London, Routledge).

Turnock, D. (2001) 'Railways and Economic Development in Romania before 1918', Journal of Transport Geography, 9, 2.

Turnock, D. (2006) The Economy of East Central Europe 1815-1989: Stages of Transformation in a Peripheral Region (New York, NY, Routledge).

Wolfe, R. I. (1963) Transportation and politics (New York, NY, Van Nostrand).

Zartaloudis, I., Karatolos, D., Koutelidis, D., Nathenas, G., Fasoulas, S. \& Filippoupolitis, A. (1997)

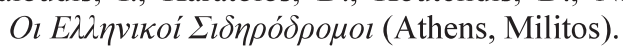

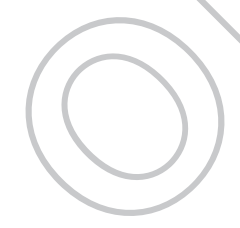

